\title{
THE USE OF THE MODERN TECHNOLOGY IN EDUCATIONAL WORK: USER STUDY FOR DIGITIZATION OF CULTURAL HERITAGE
}

\author{
MiLica LaJBENŠPERGER \\ stanojko@sezampro.rs \\ National Employment Service, Serbia \\ MARIJA ŠEGAN \\ msegan@mi.sanu.ac.rs \\ Serbian Academy of Sciences and Arts, Serbia \\ SANJA RAJIĆ \\ rsanja73@gmail.com \\ School for Mechanical and Electrical Engineering \\ "Goša" in Smederevska Palanka, Serbia
}

\begin{abstract}
In the Republic of Serbia the idea that the digitization of cultural heritage could be used to popularize and utilize modern technologies in education was first realized in 2012. One of the results of this project was a user study. In this paper we indicate some of project's fragments and present some of the results of the conducted research.
\end{abstract}

Key words: digitization, cultural heritage, education, user study.

\section{INTRODUCTION}

The development of a national project that makes use of the digitization of cultural heritage to popularize and utilize new technologies in education of the Republic of Serbia ${ }^{1}$ has been prompted by two circumstances. First, the digital preservation of cultural heritage is listed as one of the priorities of the current strategy of the development of science and technology in the Republic of Serbia. Second, Serbia has recently adopted a program that aims at promoting scientific and technological knowledge among young people. In 2012, more than one hundred high school teachers and students from the Podunavlje District in Serbia (School for Mechanical and Electrical Engineering Goša in Smederevska Palanka and Gymnasium of Velika Plana in Velika Plana) were familiarized with the basic principles of the digitization of cultural heritage and trained to apply the new knowledge in the school curriculum. One of the results of the monitoring and evaluation of their work was the creation of a user study that brought together the authors of this paper.

It was necessary to devise a user study to answer the following questions: Can the digitization of cultural heritage be of any use to teachers and students

To read more about the project: Digitization of cultural and scientific heritage with applications in high school and university teaching of mathematics, computer science, astronomy, history, and Serbian language, 2011. 
(users) and can it facilitate their educational and scientific work? What is the practical value of digital contents and digital repositories in general? The concept of digitization can most often be encountered in the fields of (social) marketing. Essentially, it points to the fact that a product has no practical value if it has no users. Other similar projects realized to date have underscored the importance of user category. Still, when it comes to the issues of material selection, digitization and presentation, the decisions are made solely on the level of creators (stakeholders and aggregators). In such cases, users are never consulted. The question thus remains whether users "seem too predictable and obvious to be addressed properly" (Dobreva, 2012, p. 3). As the presentations of digital content and repositories are actually perceived as a kind of service whereby the needs, expectations and perception of the user (Feliciati, 2012) should be taken into account, there is an obvious need for research on how different users, or rather different groups of users, may contribute to the development of such kind of service. The questions above have prompted the authors of this paper to develop a user study which would, among other things, examine (1) the compatibility between the goals of the creators of digital content and the repository, and (2) the users' expectation, or to be more precise, to what extent the expectations of those users have been met.

While gathering data for this user study, first we applied face-to-face in-depth interview with experts/creators of digital repositories ${ }^{2}$ and then questionnaires to poll the project participants/students. In order to measure the number of visits and conduct a quantitative analysis of the visitors of the digital repository's web presentation (споменика културе у Србије [Cultural monuments of Serbia], 2013) or, in other words, the digital content users, we made use of the tools that are already offered in the Google Analytics package (see Google Analytics, 2013). For measuring how the study participants' competence concerning the digitization of local immovable cultural heritage has been enhanced, the school accomplishments were analyzed, based on the following data: school grades before, during and after the participation in the project. The data collected from the questionnaires were input and processed in the program package SPSS for Windows, using descriptive statistical methods.

\section{SOME RESULTS OF THE USER STUDY}

In the present paper we do not intend to offer a detailed analysis of data obtained in the user study ${ }^{3}$. Instead, we seek to point out several factors that seem to be significant for the digitization of cultural heritage and its application in education. This study shows that more than half of the students (55.2\%) included in the

\footnotetext{
2 In-depth interview is one of the techniques used in qualitative research. It gives deeper insight into the researched topic, as the interviewed subjects can express their beliefs, attitudes, behavior and motivation in more detail.

3 A detailed user study is planned to be published: Lajbenšperger, Šegan, \& Rajić, 2012.
} 
survey ${ }^{4}$ were not familiar with the cultural monuments in their region; the other half were either averagely $(24.1 \%)$ or very well $(20.7 \%)$ informed. When enquired about the most common source of information, the students pointed to electronic media, for example, the internet-based encyclopedia Wikipedia, in combination with printed and oral sources. Two of the respondents stated that their parents and elder people are their sole source of information. As for the national digital catalogues (digital repositories) of cultural monuments, some of the students (41.38\%) admitted they had no previous knowledge of them. This observation is interesting, especially in view of the fact that for years now there have been several national digital catalogues of cultural monuments ${ }^{5}$ whose contents are constantly used (il)legally by international internet-based encyclopedias, including Wikipedia, which raises the question of general popularity of the local repository presentation.

In response to the question why there is any work done on the digitization of scientific and cultural goods, we received various answers, which could be divided into four categories: (1) easier access to the cultural monuments, development of tourism, preservation and education (see Figure 1).

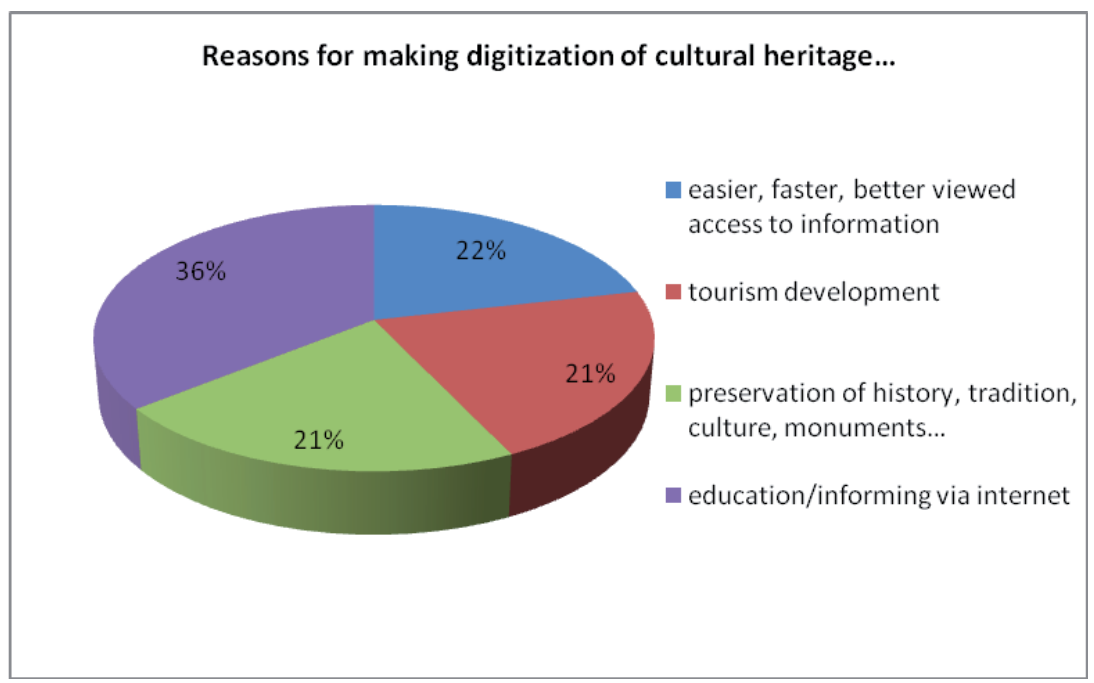

Fig.1. The students' reply on the point of cultural properties digitization. Source: Own chart (Lajbenšperger, \& Rajić, 2012).

4 The survey included 30 students attending the School for Mechanical and Electrical Engineering "Goša" in Smederevska Palanka and Gymnasium of Velika Plana in Velika Plana.

5 Among the projects of systematic digitization of cultural heritage in Serbia, we would like to point out the following: The project of immovable cultural properties database created by the Republic Institute for cultural monument preservation [http://www.heritage-db.org/cir/pretraga]; the presentation of the Catalogue of immovable cultural property on the territory of Belgrade, by the Belgrade Institute for cultural monument preservation (Завод за заштиту споменика културе града Београда [Institute for Protection of Cultural Monuments], 2013); the project of the unofficial foundation Blago (Treasure) (БЛАГО Treasure [Blago Treasure], 2013); Digital catalogue of Cultural monuments of the Mathematical Institute of Serbian Academy of the Sciences and Arts (Cultural monuments in Serbia, 2013) and Archaeological project Viminacium (Viminacium Rimski grad i utvrđenje [Viminacium roman town and fortress], 2013. 
It is interesting to register that, as the in-depth interview has indicated, the creators of the digital repositories partially agreed with the participants of the survey. They pointed out that the primary goal of digitization is the specific type of protection and preservation of cultural properties, and that the digital content is valuable in itself as it can be used for various types of studies concerning new technologies.

Similarly, when analyzing the data pertaining to another open issue, namely, the identity and profile of digital contents and repositories users, we once again found ourselves faced with the problem of multiple answers. This time, however, it was difficult to group the answers into any logical categories. In order to get some general insight into the way the students think, these answers have also been classified into several categories (see Figure 2).

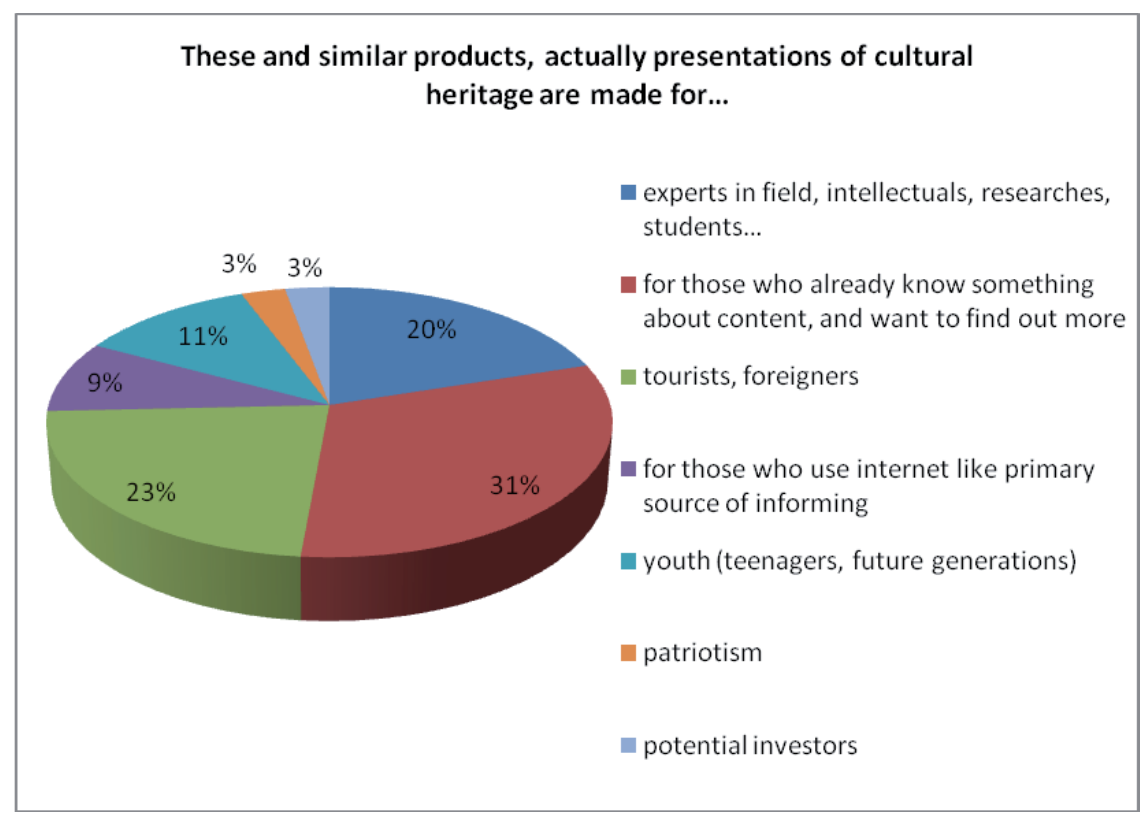

Fig. 2. The reply of the participants on the users of digital contents and resources. Source: Own chart (Lajbenšperger, \& Rajić, 2012).

It has to be kept in mind that the students were not the only ones confused by question about who could be the final users of digital contents and resources. Based on in-depth interviews with the experts, the information obtained points to the fact that in the creation of digital repositories, the target group has not been profiled in advance; additionally, the users of the products of digitization of cultural heritage can be divided into two target groups: (1) the general public, which obtains information about digitalized heritage through mass media, especially through internet media (e.g. websites and social media pages) and enjoys a certain cultural heritage monument in a particular way, and (2) the researchers, who are able to explore a much larger amount of data than before. Answers given by the experts regarding the questions about the purpose of digitizing cultural heritage 
materials and about the users of those materials would probably be more concise if there was some unique strategy to be followed ${ }^{6}$.

When evaluating the contents and technical characteristics of the digital repository in question (the Digital catalogue of Cultural monuments of the Mathematical Institute), the students who participated in the survey rated the graphical design of the web presentation very poorly. In their opinion, the presentation should have a more modern and attractive layout. For example, the layout of the home page should be changed so that potential users could be drawn and introduced to the contents of the website. This observation was later confirmed by the number of visits of the digital catalogue, monitored through Google Analytics, which showed that the percentage of those leaving the presentation right after viewing the home page was as high as $68.19 \%$. In other words, the users found no further encouragement to carry on their exploration of the presentation. Such an evaluation motivated the creators to ask the students to give their own suggestions on how to improve the graphical design of the website, and the students answered promptly. Most of them suggested adding animations and video clips, and to make the website more interactive (see Figure 3).

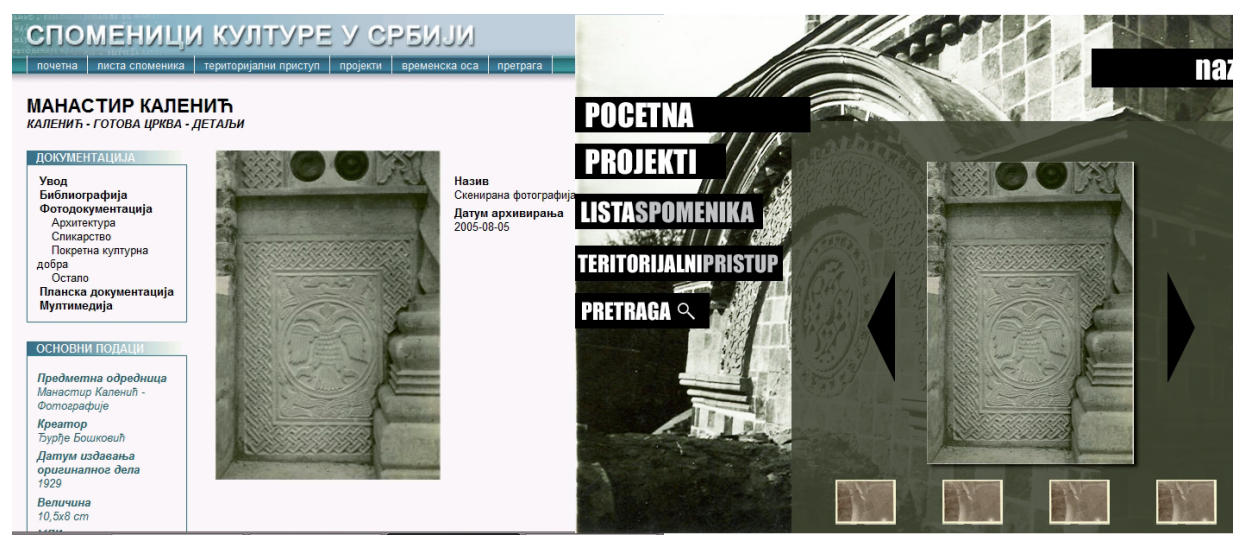

Fig. 3. Current graphical design of a digital repository "Cultural Monuments of Serbia", on the left, and the suggestion of students, on the right.

Source: Own photo (Mathematical Institute SASA, 2012).

We must bear in mind that the suggestions offered by the students were entirely voluntary, which supports students' claim that they strive for self-improvement and contribution. In this way, the creators gained insight into the expectations of a particular user category, which also enabled them to find the direction they should take when further developing and polishing their presentation.

\footnotetext{
Although defined as one of the priorities of the Serbian Ministry of Culture and Information, there are no official national strategies or standards regarding the question of the digitization of cultural heritage. Under such circumstances, the cultural and scientific institutions in Serbia rely mainly on the European recommendations of the standards (such as EUROPEANA and DARIAH) in developing their own methodology. The result of that is reflected in the variety and inconsistency of the existent strategies.
} 
Through an analysis of the students' school achievements reflected in school grades before, during and after their participation in the project, the user study also included a phase of monitoring the improvement of competence (knowledge and skills) of the participating students. The study showed that the average grade in certain subjects has increased among the students who participated in the project (see Figures $4 \mathrm{a}$ and $4 \mathrm{~b}$ ).

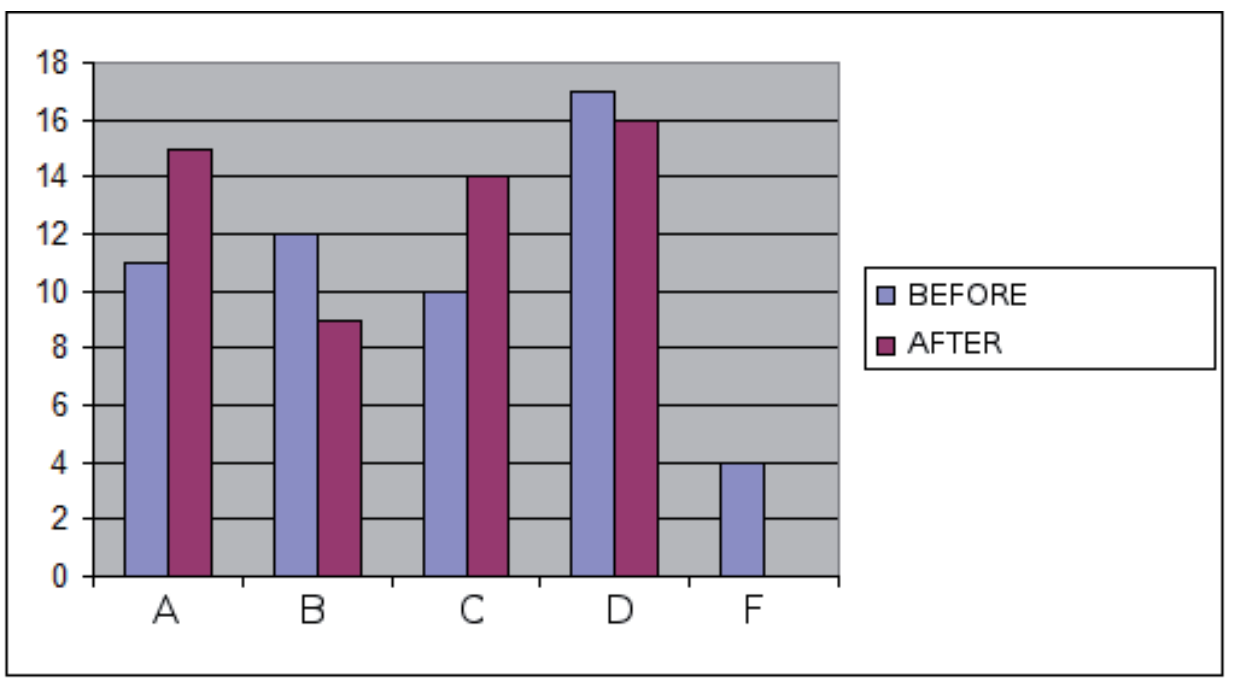

Fig. 4a. History grades in two first year classes of the School for Mechanical and Electrical Engineering Goša in Smederevska Palanka before and after the Project. Source: Own chart (Lajbenšperger, \& Rajić, 2013).

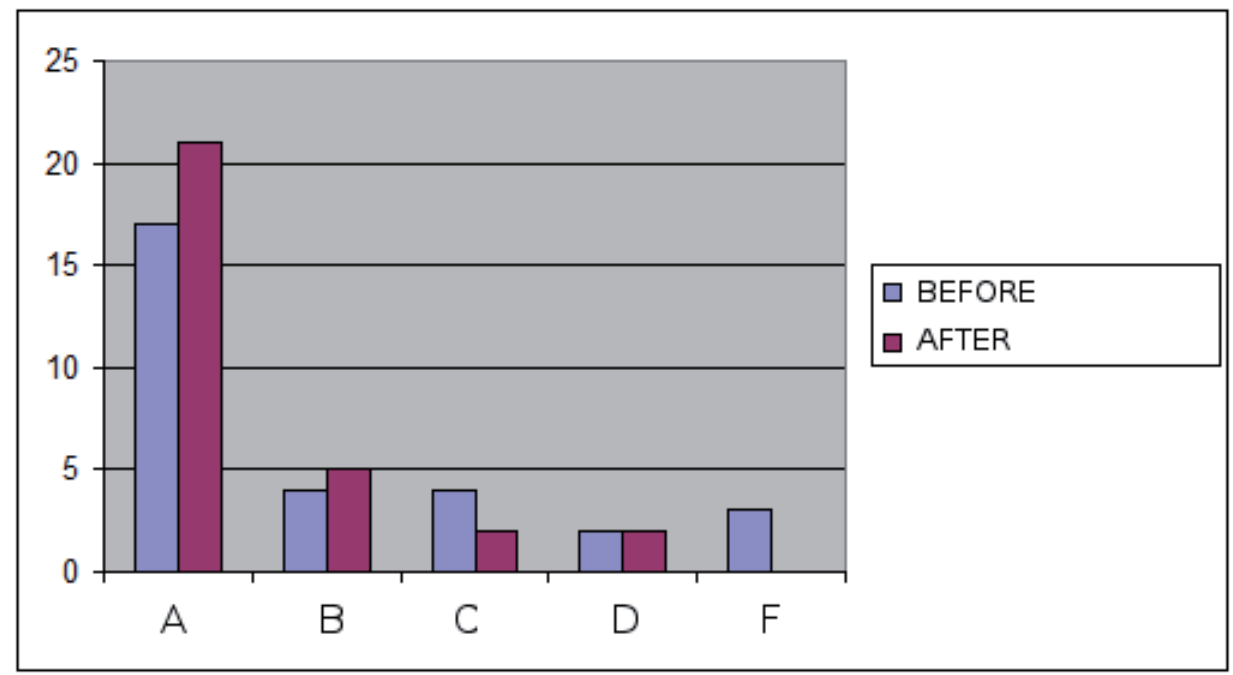

Fig. 4b. Programming grades in one fourth year class of the Electronic Engineering school Goša in Smederevska Palanka before and after the Project.

Source: Own chart (Lajbenšperger, \& Rajić, 2013). 
Noteworthy at this point is the case of a student who had a failing grade in programming, but after participating in the project and writing a paper on digital database development, his grade rose to A. Naturally, we must bear in mind that school grades are only one of the ways to evaluate the level of competence (knowledge and skill) and development in certain subjects. Therefore, they cannot be considered as the absolute criteria of competence improvement, as there are numerous other factors which affect their change over the course of time.

\section{CONCLUSION}

It can be concluded that digital contents and repositories present a convenient way of rapid and massive dissemination not only of different products of digitization, but also of culture and science in general. The creators of digital repositories are supposed to define in advance the current needs of society and, therefore, to consider, among other things, the target user of digital content. Our study shows that, besides the two large target groups of digitization of cultural heritage users -the researchers (for example, scientists, professors, educated experts) and the general public (for example, tourists and all other people interested in this type of content) - they should also consider the needs of the younger population (students, alumni) and perceive them as a special group. Young people can also be considered a part of the general public, but it is very important to bear in mind the specific requirements and expectations of this group of users, who spend more than 20 hours a week online, not only for fun and communication, but also for the purpose of educating themselves (see Figure 5).

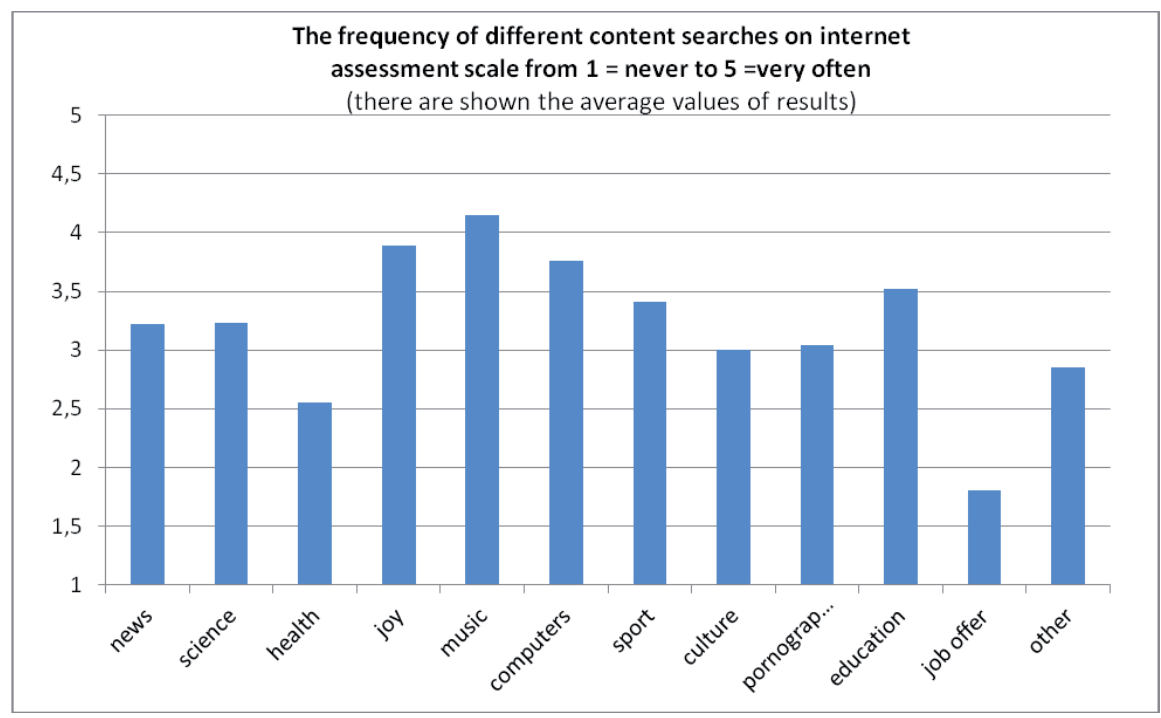

Fig. 5. The answers of survey participants regarding the search of certain contents online, in which education holds a very high place.

Source: Own chart (Lajbenšperger, \& Rajić, 2012). 
Their comments and suggestions may help the creators make digital contents and repositories more interesting, attractive and interactive, which gives one more dimension to the practical value of digitized heritage in general. The online presentation of digital content and repository is the mediator and service that should change in relation to the expectations of "future generations", but also with the aim to influence their perspective and participation. The results of our analysis indicate a rise in awareness of the benefits of using the digitization of cultural heritage not only in education, but also for self-improvement. The user study devised by us should, in the long run, facilitate the development of methodological and technical procedures for studying and monitoring the use of digital contents and repositories, as well as users.

\section{REFERENCES}

БЛАГО Treasure [Blago Treasure]. 2013. Retrived from http:/ / www.srpskoblago.org.

споменика културе у Србије [Cultural monuments of Serbia]. 2013. Retrived from http:/ / spomenicikulture. mi.sanu.ac.rs/.

Завод за заштиту споменика културе града Београда [Institute for Protection of Cultural Monuments]. 2013. Retrived from http:/ / beogradskonasledje.rs/aktuelnosti/katalog-nepokretnih-kulturnih-dobara.

Cultural monuments in Serbia. 2013. Retrived from http:/ / spomenicikulture.mi.sanu.ac.rs/.

Digitization of cultural and scientific heritage with applications in high school and university teaching of mathematics, computer science, astronomy, history, and Serbian language. (2011). Retrived from http://www. mi.sanu.ac.rs/projects/popularizacija_2011_digit_en.pdf.

Dobreva, M., O’Dwyer, A., \& Feliciati, P. (2012). User Studies for Digital Library Development. London: Facet Publishing.

Feliciati, P., \& Alfier, A. (2012). Archives on the Web and users expectations towards a convergence with Digital Libraries. Paper presented at SEEDI conference in Ljubljana, May, 16 - 18, 2013. Retrieved from http://www.nuk.uni-lj.si/dokumenti/2012/seedi/5_3_Presentazione_Seedi-AlfierFeliciatidef.pdf.

Google Analytics. 2013. Retrived from http:/ / www.google.com/analytics/.

Kotler, P., Armstrong, G., Saunders, J., \& Wong, V. (1996). Principles of marketing. European edition: Prentice Hall.

Lajbenšperger M., Šegan M., Rajić S. (2012), Studija korisnika Elektronskog kataloga Spomenika kulture. An unfinished version currently available in the archives of the Mathematical institute of SANU.

Law on Amendments to the Law on Scientific Research. (2010). Official Gazette of the Republic of Serbia, $18 / 2010$.

Manžuch, Z., Huvila, I., \& Aparac-Jelušić, T. (2005). Digitization of Cultural Heritage. In: L. Kajberg (Ed.), European Curriculum Reflections on Library and Information Science Education (pp. 37-65). Copenhagen: The Royal School of Library and Information Science.

Mathematical Institute SASA. (2011). Digitization of cultural and scientific heritage with applications in high school and university teaching of mathematics, computer science, astronomy, history, and Serbian language. Retrieved from http:/ / www.mi.sanu.ac.rs/projects/popularizacija_2011_digit_en.pdf.

Rizvić, S., Sadžak, A., Hulušić, V., \& Karahasanović, A. (2012). Interactive Digital Storytelling in the Sarajevo Survival Tools Virtual Environment. In: J. K. Hollingsworth (Ed.), Proceedings of the International Conference on High Performance Computing, Networking, Storage and Analysis (pp. 109-116). New York: ACM New York.

Siatri, R. (1999). The Evolution of User Studies. Libri, 49, 132 - 141.

Strategy for the Development of Scientific and Technological Development of Republic of Serbia (2010 - 2015). (2010). Ministry of Science and Technological Development of the Republic of Serbia.

Šola, T. (2002). Marketing u muzejima. Beograd: Clio.

Viminacium Rimski grad i utvrđenje [Viminacium roman town and fortress]. 2013. Retrived from http:/ / www.viminacium.org.rs/ Architecture/index.html?language=srpski. 